\title{
High Performance Infiltrated Backbones for Cathode-Supported SOFC's
}

\section{Gil, Vanesa; Kammer Hansen, Kent}

Published in:

ECS Transactions

Link to article, DOI:

10.1149/06402.0041ecst

Publication date:

2014

Document Version

Publisher's PDF, also known as Version of record

Link back to DTU Orbit

Citation (APA):

Gil, V., \& Kammer Hansen, K. (2014). High Performance Infiltrated Backbones for Cathode-Supported SOFC's. ECS Transactions, 64(2), 41-51. https://doi.org/10.1149/06402.0041ecst

\section{General rights}

Copyright and moral rights for the publications made accessible in the public portal are retained by the authors and/or other copyright owners and it is a condition of accessing publications that users recognise and abide by the legal requirements associated with these rights.

- Users may download and print one copy of any publication from the public portal for the purpose of private study or research.

- You may not further distribute the material or use it for any profit-making activity or commercial gain

- You may freely distribute the URL identifying the publication in the public portal

If you believe that this document breaches copyright please contact us providing details, and we will remove access to the work immediately and investigate your claim 


\title{
High performance infiltrated backbones for cathode-supported SOFC's
}

\author{
V. Gil and K. Kammer Hansen \\ Department of Energy Conversion and Storage, Technical University of Denmark (DTU), \\ Roskilde 4000, Denmark
}

\begin{abstract}
A four-step infiltration method has been developed to infiltrate $\mathrm{La}_{0.75} \mathrm{Sr}_{0.25} \mathrm{MnO}_{3+\delta}$ (LSM25) nanoparticles into porous structures (YSZ or LSM-YSZ backbones). The pore size distribution in the backbones is obtained either by using PMMA and/or graphites as pore formers or by leaching treatment of samples with Ni remained in the YSZ structure at high temperatures. All impregnated backbones, presented Rs comparable to a standard screen printed cathode, which proves that LSM nanoparticles forms a pathway for electron conduction.
\end{abstract}

\section{Introduction}

Ohmic loss of the electrolyte and cathodic polarization resistance are two key issues that hinder Solid oxide fuel cells (SOFC) lowering operation temperature down to the range $500-800{ }^{\circ} \mathrm{C}$. The ohmic loss can be decreased by the reduction of the thickness of the electrolyte or by choosing materials with faster ionic transport over yttria stabilized zirconia (YSZ) [1-2]. To decrease the cathodic polarization, alternative materials to the standard $\mathrm{La}_{1-\mathrm{x}} \mathrm{Sr}_{\mathrm{x}} \mathrm{MnO}_{3+\delta}$ has been explored [3-4]. However, at present, most SOFC use yet the standard composite $\mathrm{La}_{1-\mathrm{x}} \mathrm{Sr}_{x} \mathrm{MnO}_{3+\delta}-\mathrm{YSZ}$ as the cathode. An alternative to enhance oxygen reduction reaction catalysis in the cathode is the infiltration of LSM nanoparticles in a pre-sintered and well-connected oxygen ion-conducting network,YSZ backbone where the nanoparticles form a thin and uniform layer on the pore walls of the electrode's network. This concept was first reported in a patent literature in 1968 [5] and revised by Isenberg a few decades later [6]. In this study we report a four-step infiltration technique to prepare cathodes with as high as $30 \mathrm{wt} . \%$ of LSM nanoparticles. The microstructural features and electrochemical performance is discussed by comparing backbones where the porosity is obtained by using pore formers or by Ni-leaching process.

\section{Experimental}

\section{$\underline{\text { Backbones development }}$}

The powders used in the present study were $\mathrm{Y}_{0.15} \mathrm{Zr}_{0.85} \mathrm{O}_{1.95}\left(8 \mathrm{~mol} \% \mathrm{Y}_{2} \mathrm{O}_{3}\right.$ stabilised $\mathrm{ZrO}_{2}$ - 8YSZ) from Tosoh, Japan and $\left(\mathrm{La}_{0.75} \mathrm{Sr}_{0.25}\right)_{0.95} \mathrm{Mn}_{1.05} \mathrm{O}_{3+\delta}$ (LSM) from Haldor Topsøe A/S, Denmark. Graphite from Alfa Aesar and PMMA from Esprix technologies were used as pore formers.

The cathodes were obtained by infiltrating LSM into a sintered either $300 \mu \mathrm{m}$ thick YSZ backbone structure, BB, or a 10-15 $\mu \mathrm{m}$ thick YSZ backbone electrode layer, BBE, 
integrated onto a $300 \mu \mathrm{m}$ thick LSM-YSZ support layer, BBS, samples hereafter called BBS-BBE. The fabrication of the half cells was complete with the integration of a thin standard electrolyte, 10-15 $\mu \mathrm{m}$ YSZ, in house tape casted. A sketch of the cross section of the samples assessed is shown in Figure 1.

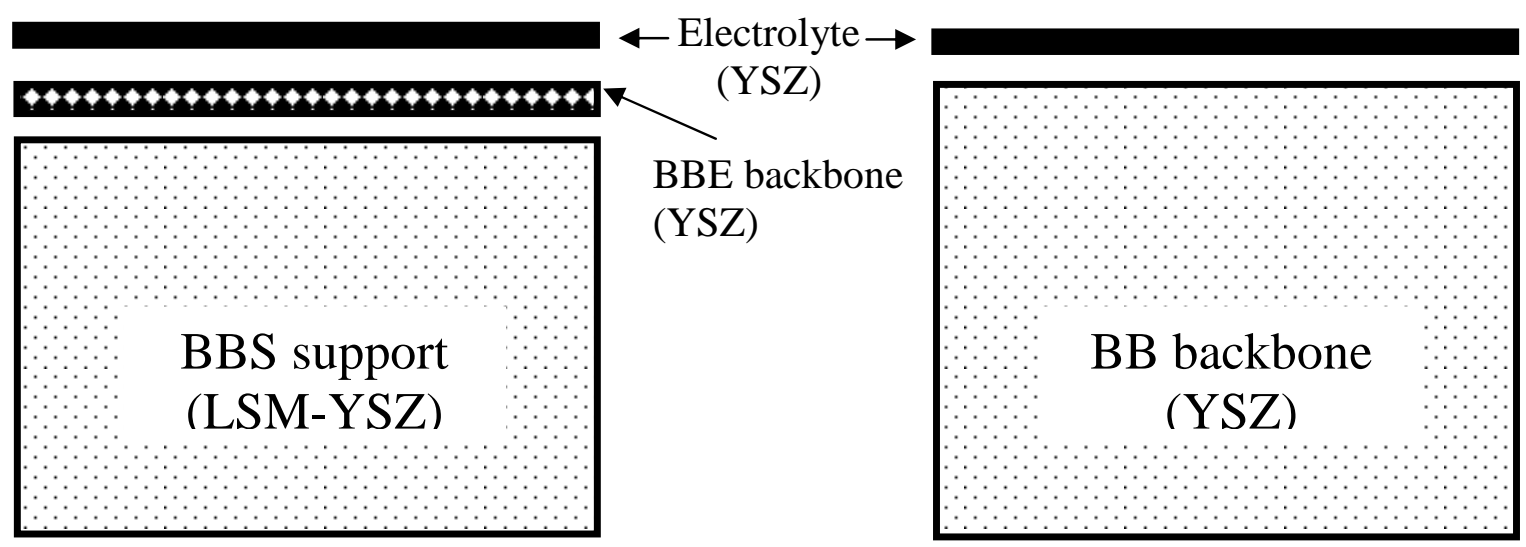

Figure 1. Sketch of the cathode supported half cells with the backbones used for LSM infiltration.

Porous $300 \mu \mathrm{m}$ thick YSZ backbones, BB, were prepared by etching anode-supported half cells produced at DTU Energy Conversion, consisted of Ni-YSZ support/Ni-YSZ electrochemically active anode/YSZ electrolyte. The half cells were fabricated by the same procedure as described in [7]. The sintered casted tapes were reduced at $800-850{ }^{\circ} \mathrm{C}$ for $1 \mathrm{~h}$ with $10 \% \mathrm{H}_{2}$-Ar atmosphere. Subsequently, the etching process removes the nickel by using an acidic solution of $\mathrm{HNO}_{3} 2.2 \mathrm{M}$ at $80{ }^{\circ} \mathrm{C}$ for $24 \mathrm{~h}$ resulting in a YSZ backbone with a thickness of about $300 \mu \mathrm{m}$.

For backbones BBS-BBE the slurry formulation for the fabrication of the LSM-YSZ support and thin YSZ backbone follows the guidelines reported in a previous work for the fabrication of LSM-CGO backbones [8]. In addition to the raw powders, type and amount of pore formers and adjustment of solvent, dispersant and binder/plasticizer content were modified according to Table I. LSM powders calcined at $950{ }^{\circ} \mathrm{C}$ and $1200{ }^{\circ} \mathrm{C}$ were mixed in the ratio 4:6 in an azeotropic mixture of methylethylketone and ethanol (MEKET) with polyviniylpyrolidone (PVP) and ball milled for $72 \mathrm{~h}$. YSZ raw powder and calcined at $1100{ }^{\circ} \mathrm{C}$ were added to the slurry in the ratio 1:1. in addition to PVP and MEKET. After $24 \mathrm{~h}$ ball milling pore formers were added to the suspension and milled for $4 \mathrm{~h}, 13.2 \mathrm{wt} . \%$ PMMA microparticles (of total solid content) and 7.9 wt.\% graphite (of total solid content). Finally a mixture of binder and plasticizer was added to the suspension and milled overnight.

A similar procedure was used for fabrication of the thin YSZ backbones. After $48 \mathrm{~h}$ of milling the YSZ suspension PMMA microparticles was added to the suspension, 16.2 wt. $\% 2 \mu \mathrm{m}$ and $16.2 \mathrm{wt} . \% 5 \mu \mathrm{m}$ (of total solid content) and ball milled for $4 \mathrm{~h}$. After adding binder/plasticizer the slurry was milled overnight.

Dried tapes were laminated at $140^{\circ} \mathrm{C}$ as follows: 2 layers LSM-YSZ composite with 1 layer YSZ backbone and subsequently sintered in air between 1225 and $1350^{\circ} \mathrm{C}$ for $5 \mathrm{~h}$. 
TABLE I. Slurry composition will all the values in grams.

\begin{tabular}{lcc}
\hline & $\begin{array}{c}\text { BBS backbone } \\
\text { (LSM-YSZ) }\end{array}$ & $\begin{array}{c}\text { BBE backbone } \\
\text { (YSZ) }\end{array}$ \\
\hline LSM 1200 ${ }^{\circ} \mathrm{C}$ & 95 & \\
LSM 950 ${ }^{\circ} \mathrm{C}$ & 63 & \\
PVP $(33 \%)$ in MEKET & 10 & 50 \\
MEKET & 165 & \\
YSZ $\left(3 \% \mathrm{Y}_{2} \mathrm{O}_{3}\right)$ & 86 & 36 \\
YSZ $\left(3 \% \mathrm{Y}_{2} \mathrm{O}_{3}\right) 1100^{\circ} \mathrm{C}$ & 86 & 3 \\
YSZ $\left(8 \% \mathrm{Y}_{2} \mathrm{O}_{3}\right)$ & 10 & 9 \\
PVP $(33 \%)$ in MEKET & 55 & 9 \\
PMMA $\left(\mathrm{d}_{50}=5 \mu \mathrm{m}\right)$ & & \\
PMMA $\left(\mathrm{d}_{50}=2 \mu \mathrm{m}\right)$ & 33 & 107 \\
Graphite $\left(\mathrm{d}_{50}=2.6 \mu \mathrm{m}\right)$ & 300 & \\
Binder & & \\
\hline
\end{tabular}

\section{$\underline{\text { Infiltration method }}$}

Two different methods were used to add the LSM to the porous YSZ or composite LSM-YSZ structures. One method consisted of immersion of the backbone structures into the precursor solution at room temperature followed by rough vacuum $(\sim 1 \mathrm{mbar})$ to enhance the penetration of the solution by capillary forces. The second method of infiltration involved vacuum prior to impregnation. The vacuum ( $\sim 15 \mathrm{mbar})$ was applied to the composite/backbones during $15 \mathrm{~min}$ and subsequently the LSM solution penetrated into the porous structures under vacuum $(\sim 15 \mathrm{mbar})$ during $10 \mathrm{~min}$. The idea is the removal, prior to infiltration, of the trapped air in the pores to promote the penetration of the aqueous solution into the backbone.

In both methods, the precursor solution was based on an aqueous solution of metal nitrates corresponding to the nominal composition $\mathrm{La}_{0.75} \mathrm{Sr}_{0.25} \mathrm{Mn}_{1.05} \mathrm{O}_{3+\delta}$ (LSM). $\mathrm{La}\left(\mathrm{NO}_{3}\right)_{3} \cdot 6 \mathrm{H}_{2} \mathrm{O}$ (Alfa Aesar, USA), $\mathrm{Sr}\left(\mathrm{NO}_{3}\right)_{2}$ (Riedel-de Haen, Germany) and $\mathrm{Mn}\left(\mathrm{NO}_{3}\right)_{2} .5 \mathrm{H}_{2} \mathrm{O}$ (Alfa Aesar, USA) were dissolved in distilled water to give a solution 3 $\mathrm{Mm}$ and a few drops of a surfactant was added. The infiltration process was repeated to obtain higher LSM loadings. After each step, the infiltrated samples were heated to 600 ${ }^{\circ} \mathrm{C}$ to decompose the nitrate ions and form the mixed oxides. Finally, the samples were fired at $900{ }^{\circ} \mathrm{C}$ to form the perovskite phase.

\section{Characterization}

The phase composition of the sintered supports LSM-YSZ and reduced NiO-YSZ tapes was analyzed by X-ray powder diffraction (XRD) at room temperature using a Bruker D8 Advance diffractometer with $\mathrm{Cu} \mathrm{K \alpha}$ radiation. The microstructural analysis of the samples, before and after LSM infiltration, was carried out using a Zeiss Supra 35 scaning electron microscope (SEM) equipped with a field emission gun and an EDS detector. The pore size distributions and porosities of the backbones prior to infiltration were determined using the mercury intrusion porosimetry (AutoPore XX, Micromeritics). For comparison, porosity and pore size distribution of the samples before infiltration was estimated by image analysis where images were quantified semi-automatically by the 
mean linear intercept method using the program ManSeg v0.35@Jacob R. Bowen, DTU Energy Conversion. Permeability through the porous substrates and backbones was assessed using an in-house designed spotwise leak testing system. The leakrate was measured by contacting the porous sample with a rubber seal of internal diameter $1.5 \mathrm{~cm}$, applying a vacuum, leaving to equilibrate for $10 \mathrm{~min}$ and recording the air gas flow throughout the sample and pressure drop. The permeability coefficient was determined using a rearranged form of Darcy's law [9]:

$$
k=v \cdot \mu \cdot \frac{\Delta h}{\Delta p}
$$

where $k$ is the permeability factor $\left(\mathrm{m}^{2}\right) ; \nu$ the superficial velocity $(\mathrm{m} / \mathrm{s}), \mu$ the fluid viscosity of the gas ( $\mathrm{Pa} \mathrm{s}), \Delta h$ the thickness of the substrate (m) and $\Delta P$ the pressure drop across the substrate $(\mathrm{Pa})$.

The air viscosity used for the calculations was $1.85 \times 10^{-5} \mathrm{~Pa} . \mathrm{s}$ [10]. The superficial velocity of the gas used was calculated using the volumetric flow rate through the sample:

$$
v=\frac{q_{\mathrm{wal}}}{A}
$$

where $Q_{v o l}$ is the volumetric flow rate $\left(\mathrm{m}^{3} / \mathrm{s}\right)$ and $A$ the sample surface $\left(\mathrm{m}^{2}\right)$.

For the electrochemical characterization, impedance spectra in the frequency range from approximately $79 \mathrm{kHz}$ to $0.1 \mathrm{~Hz}$ with a $36 \mathrm{mV}$ perturbation were collected on quasi -symmetrical cells at 700, 750 and $800{ }^{\circ} \mathrm{C}$ in 20 vol. $\% \mathrm{O}_{2}$. For the measurements a Gamry reference 600 was used. A standard LSM-YSZ cathode was screen-printed onto the $5 \times 5$

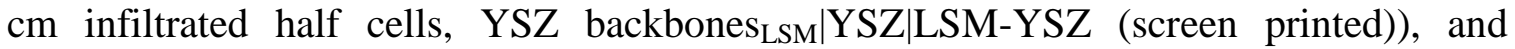
compared to standard LSM-YSZ screen printed symmetrical cells LSM-YSZ|YSZ|LSMYSZ as the reference. The quasi-symmetric infiltrated cells and the symmetrical cells as reference were cut $4 \times 4 \mathrm{~mm}^{2}$ and gold sputtering prior to impedance test.

\section{Results}

\section{Backbones characterization}

By XRD, no secondary phases were detected in the backbones BBS, LSM-YSZ, sintered at $\leq 1250{ }^{\circ} \mathrm{C}$ for $4 \mathrm{~h}$, i.e. only those peaks corresponding to a perovskite phase (LSM) and fluorite phase (YSZ) were observed in the XRD diffractograms (Fig. 2a). When samples are sintered at higher temperatures, LSM and YSZ reacts and the formation of monoclinic $\mathrm{ZrO}_{2}$ and $\mathrm{La}_{2} \mathrm{Zr}_{2} \mathrm{O}_{7}$ was detected.

Figure 3a shows a SEM image of polished cross-section of the $\mathrm{YSZ}_{(\mathrm{E}) /} \mathrm{YSZ}_{(\mathrm{BBE}) / \mathrm{LSM}}$ $\mathrm{YSZ}_{\text {(BBS) }}$ multi-layer sintered at $1250^{\circ} \mathrm{C}$. The thickness of the cells components is $\sim 10$, $\sim 15$, and $\sim 300 \mu \mathrm{m}$ for the YSZ electrolyte (E), YSZ backbone electrode (BBE) and YSZ backbone support (BBS), respectively. The micrograph shows that the dense YSZ layer 


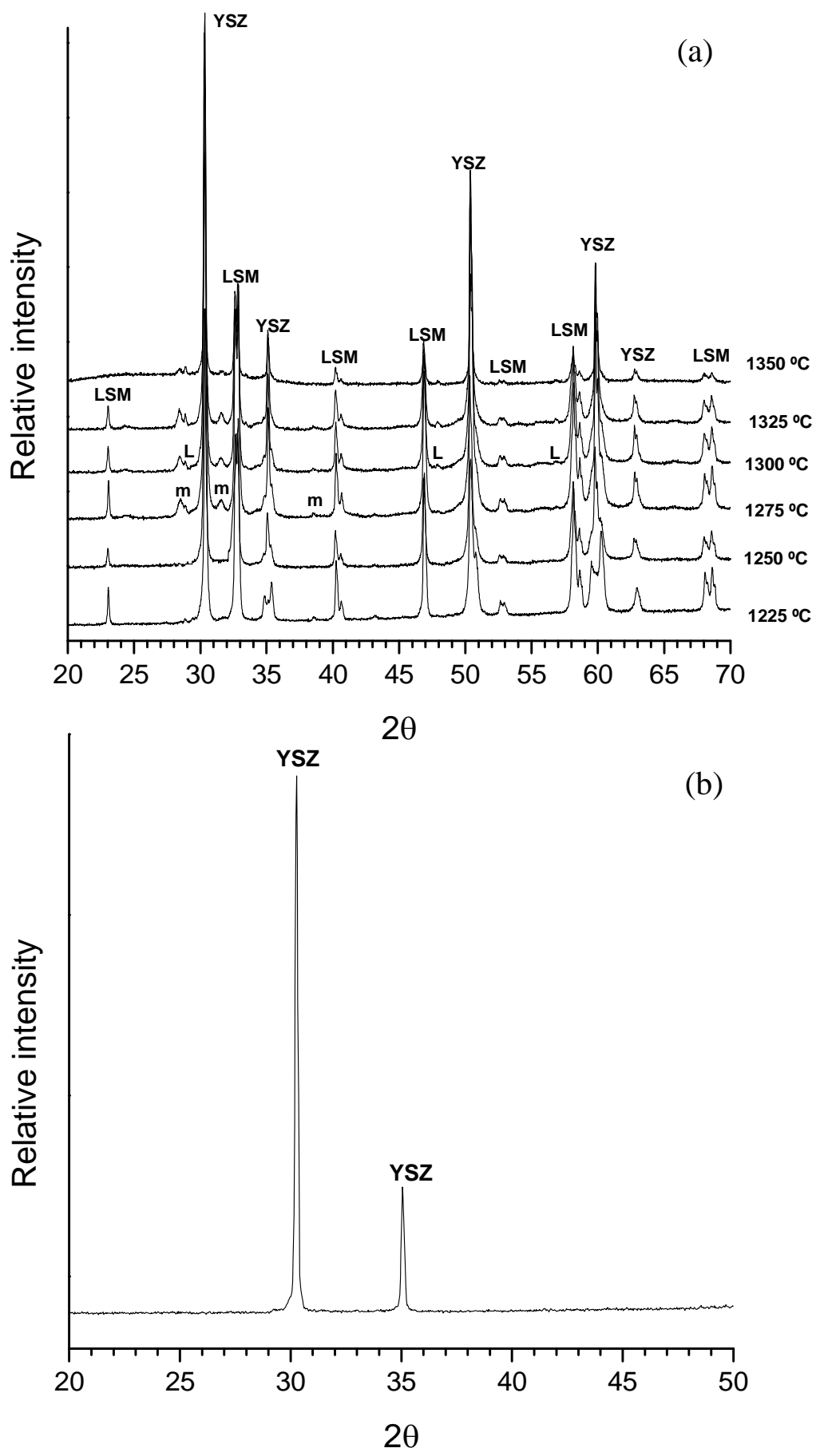

Figure 2. XRD diffractograms of (a) LSM-YSZ backbones, "BBS", sintered from 1225 to $1350{ }^{\circ} \mathrm{C}$ for $4 \mathrm{~h}$ in air. $\mathrm{m}=$ monoclinic $\mathrm{ZrO}_{2}, \mathrm{~L}=\mathrm{La}_{2} \mathrm{Zr}_{2} \mathrm{O}_{7}$. (b) $\mathrm{YSZ}$ backbone obtained from Ni-leached sample, "BB".

achieved at that temperature is suitable for his function as electrolyte, where gas-tight layer is required, as simultaneously the backbones layers remained highly porous with well interconnected pores. Spherical pores of 1.5 and $3 \mu \mathrm{m}$ were observed in the BBE backbones made with a mixture of PMMA particle sizes and both spherical and large elongated pores of several microns were observed when a mixture of PMMA and 
graphite was used, BBS. Vacuoles of $\geq 5 \mu \mathrm{m}$ in size were observed in both layers BBS and $\mathrm{BBE}$ due to the agglomeration of big particle size PMMA during slurry preparation. According to these results $1250{ }^{\circ} \mathrm{C}$ for $4 \mathrm{~h}$ was choose as the optimum sintering conditions to fabricate multilayer backbones BBS-BBE with suitable characteristics for the introduction of the electrocatalytic active phase (LSM) by post-sintering infiltration. Sintering conditions of $1225^{\circ} \mathrm{C}$ for $4 \mathrm{~h}$ was dismissed since the electrolyte densification was not sufficient for the purpose of the component cell.

It is confirmed that porous YSZ was prepared from Ni-YSZ cermets after removing the nickel by leaching. YSZ backbones, BB, prepared by first forming a Ni-YSZ network and removing the nickel by acid etching afterwards is shown in Figure $3 \mathrm{~b}$. In this case, $\mathrm{NiO}$ remained in the YSZ structure at high temperatures and acted as the pore former after reducing and leaching treatment. Microstructures with the appearance of a highly porous ceramic sponge with a random network of interconnected cavities were observed in both samples under study, reduced at 800 and $850^{\circ} \mathrm{C}$. The pore sizes did not change in a clearly regular manner with the changes in reducing conditions. It is confirmed that the nickel was effectively removed after reduction and acid leaching, where only diffraction peaks corresponded to YSZ phase are observed by XRD Figure $2 b$.
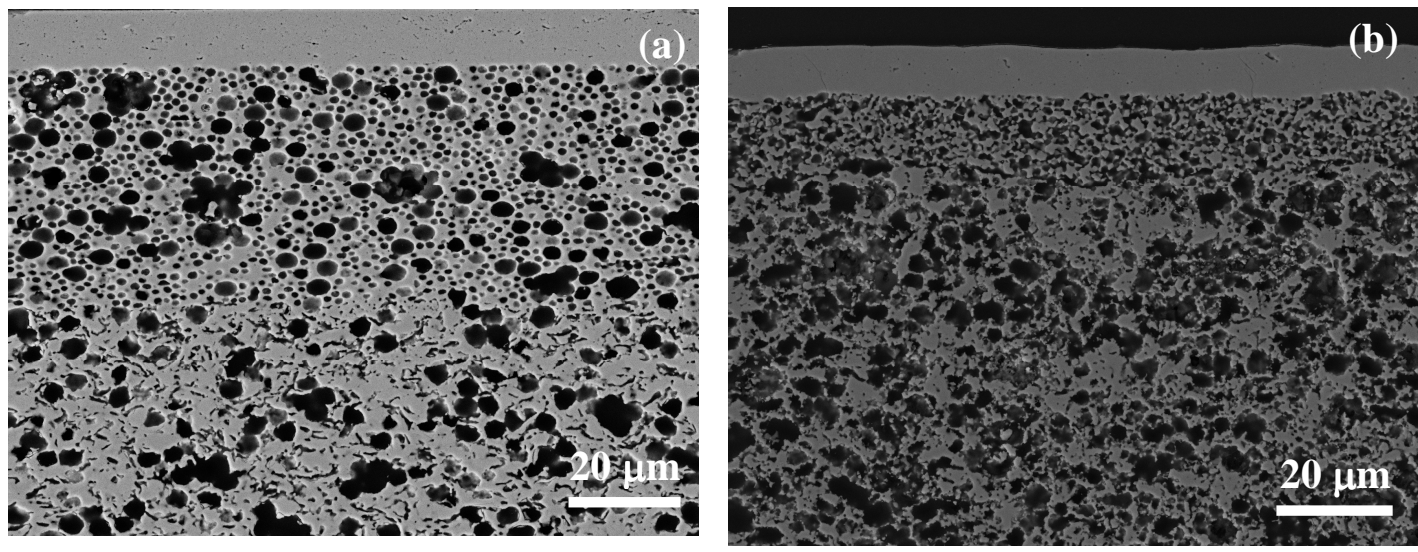

Figure 3. SEM image of the polished cross-section of (a) $\mathrm{YSZ}_{(\mathrm{E}) /} \mathrm{YSZ}_{(\mathrm{BBE}) /} \mathrm{LSM}_{\mathrm{SSO}} \mathrm{YS}_{(\mathrm{BBS})}$ sintered at $1250{ }^{\circ} \mathrm{C}$ and (b) $\mathrm{YSZ}_{(\mathrm{E}) /} \mathrm{YSZ}_{(\mathrm{BBS})}$.

Pore size distributions from mercury intrusion porosimetry are compared in Figure 4 for BB and BBS supports. Notably, the pore size distribution for the structure BB is narrower than BBS with the mean pore size approximately 0.7 and $0.9 \mu \mathrm{m}$ respectively. As expected, backbones prepared from Ni-leached structures (BB) resulted in a finer structure and the porosity increased pronouncedly from 40 to 57 vol.\% for BBS and BB respectively.

As Corbin and co-workers reported [11] the disadvantage related to the use of pore former with small particle size and spherical shape (as PMMA) result in the formation of bottlenecks pores, i.e. submicron pores connected to larger ones in the micrometer range. This issue can not be avoided unless the amount of pore former used reaches the percolation threshold. 


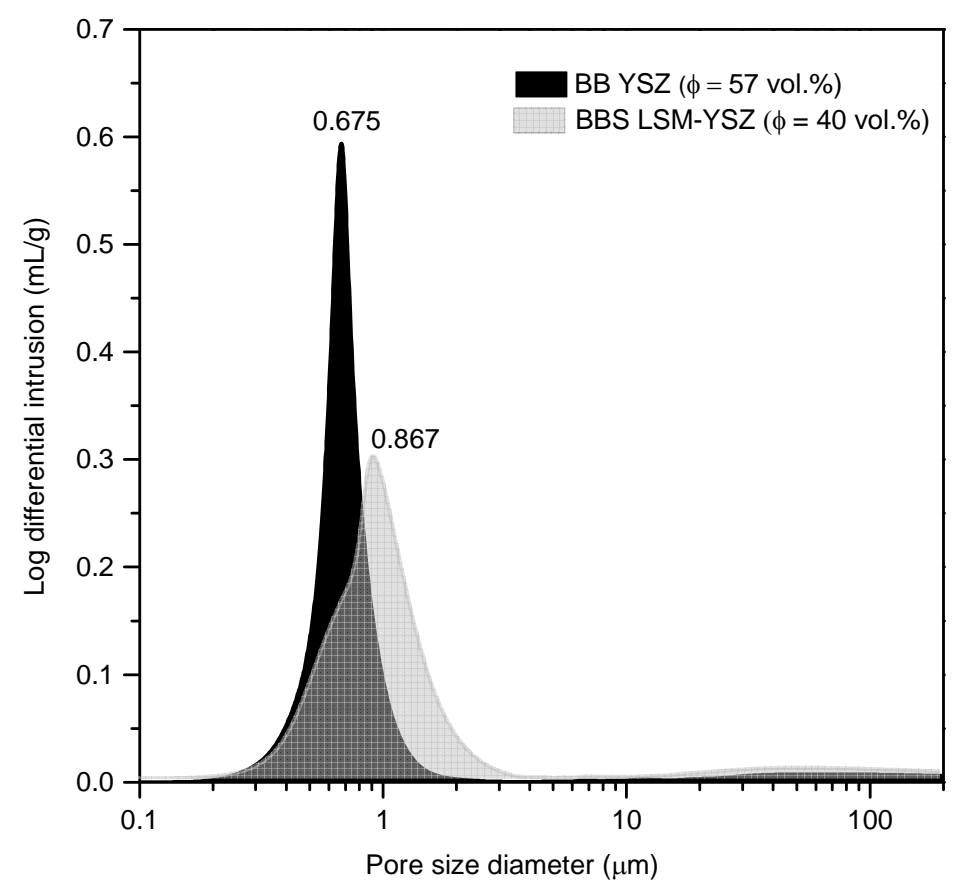

Figure 4. Pore size distribution of YSZ backbone (BB) and LSM-YSZ backbone (BBS) sintered at $1250{ }^{\circ} \mathrm{C}$ for $4 \mathrm{~h}$. The corresponding open porosity is denoted by $\phi$.

An approach to evaluate the connectivity between pores is by comparing the mean pore size obtained from mercury porosimetry with the estimated by image analysis. Since in the mercury porosimetry technique the pore size is calculated from the pressure required to push the mercury through the sample and hence the smallest diameter of the pore (bottleneck) will give the measured pore size. In our study, both mean pore sizes are compared in Table 2, similar pore sizes are determined which confirms the absence of bottlenecks when mixing PMMA with graphite.

Although the bottlenecks formation is avoided when mixing pore formers with different shape and particle size, when pore formers with spherical shape (PMMA) were used the presence of close porosity was not avoided. BB and BBS backbones with a total porosity of 58 and 47 vol.\% were estimated by image analysis, whereas an open porosity between 57 and 40 vol.\% was measured by mercury porosimetry as shown in Table 2. Similar values confirm the more efficient porous interconnectivity in the backbones BB prepared from Ni leached samples and the existence of close porosity for the YSZ backbones BBS prepared using pore formers.

In spite of the small fraction of close porosity, the backbones with open porosities higher than 40 vol\% were considered as suitable structures for the purpose of the combined electrocatalytic infiltration and gas access.

Gas permeation measurements for the samples (BBS-BBE) and the backbones (BB, BBS) were conducted in order to correlate the gas flow through the porous structure with the porous microstructures developed. The Darcian permeability coefficients, $K$, and the total porosity of the samples and backbones are included in Table II. The permeability for BB backbone, from Ni-leached sample, was a factor of 2.3 larger than that of the BBS backbone, with the use of PMMA and graphite as pore formers. Considering the microstructural development discussed in the previous section, it is clear that the gas 
permeation through the BB supports with the highest porosity content will be far easier than through the LSM-YSZ backbone support. As the backbone electrode layer (BBE) is attached to BBS supports the Darcian permeability coefficient slightly decreases. Both layers presented the same total volume percentage but the pore shape was slightly different as no graphite was used in BBE (Figure 3a). The gas permeation depends not only on the total porosity, but also on the microstructure (pore size, pore shape, interconnectivity of the pores and "tortuosity"). Despite a reduction in the total porosity for $\mathrm{BBS}$ and $\mathrm{BBE}$ backbones as compared to $\mathrm{BB}$, it is clear that the microstructures developed by mixing different kind or particle sizes of pore formers are beneficial for gas permeation (a higher fraction of large interconnected pores) as the Darcian permeability coefficient are quite close.

TABLE II. Characteristics, porosity, mean pore size and gas permeation of BB backbones from Ni-leached samples and BBS backbones and BBS-BBE multilayers sintered at 1250 ${ }^{\circ} \mathrm{C}$ for $4 \mathrm{~h}$.

\begin{tabular}{cccccc}
\hline & \multicolumn{2}{c}{ Hg porosimetry } & Image analysis & $\begin{array}{c}\text { Gas } \\
\text { permeation }\end{array}$ \\
\cline { 2 - 5 } & $\begin{array}{c}\text { Porosity } \\
(\text { Vol.\%) }\end{array}$ & $\begin{array}{c}\text { mean } \\
\text { pore size } \\
(\mu \mathrm{m})\end{array}$ & $\begin{array}{c}\text { Porosity } \\
(\text { Vol.\% })\end{array}$ & $\begin{array}{c}\text { mean } \\
\text { pore size } \\
(\mu \mathrm{m})\end{array}$ & $\begin{array}{c}K \\
\left(\mathrm{x} 10^{-15} \mathrm{~m}^{2}\right)\end{array}$ \\
\hline $\begin{array}{c}\text { LSM-YSZ Support } \\
\text { "BBS" Backbone }\end{array}$ & 40 & 0.9 & 47 & 1.5 & 1.4 \\
$\begin{array}{c}\text { BBS-BBE multilayer } \\
\text { YSZ "BB" Backbone }\end{array}$ & 57 & 0.7 & 58 & 1.1 & 0.8 \\
\hline
\end{tabular}

\section{$\underline{\text { Backbones infiltrated with LSM }}$}

The effect of using vacuum during impregnation of the backbones microstructures with aqueous LSM precursor solution was evaluated. Several trends are apparent in the data presented in Figure 5. As general rule when vacuum was applied prior to infiltration the trapped air into the pores were efficiently removed and consequently the LSM impregnation into the porous structure enhanced. When vacuum after conventional infiltration was applied, there was a more noticeably tendency to the saturation with increasing repetition steps. That is, to apply vacuum after the inmersion of the sample into the precursor solution was not as effective as the removal of the trapped air prior to infiltration and consequently the enhancement of the loading.

Figure 6 shows cross-sectional SEM images of LSM infiltrated cathodes with vacuum: BBS-BBE multilayer sample and BB backbone from Ni-YSZ sample reduced at $800{ }^{\circ} \mathrm{C}$ and Ni-leached afterwards. The cathode from BBS-BBE multilayer consists of YSZ and LSM grains, when BBS layer (and only YSZ when BBE backbone), pores, and infiltrated LSM particles with a size of less than $100 \mathrm{~nm}$. The LSM nanoparticles coat the walls of the spherical pores, forming a fairly densely packed layer of LSM nanoparticles as shown in the Figure 5b. In general, LSM nanoparticles are in close contact with each other, what is more evident in $\mathrm{BB}$ backbones where the porosity is obtained from Ni-leaching. 


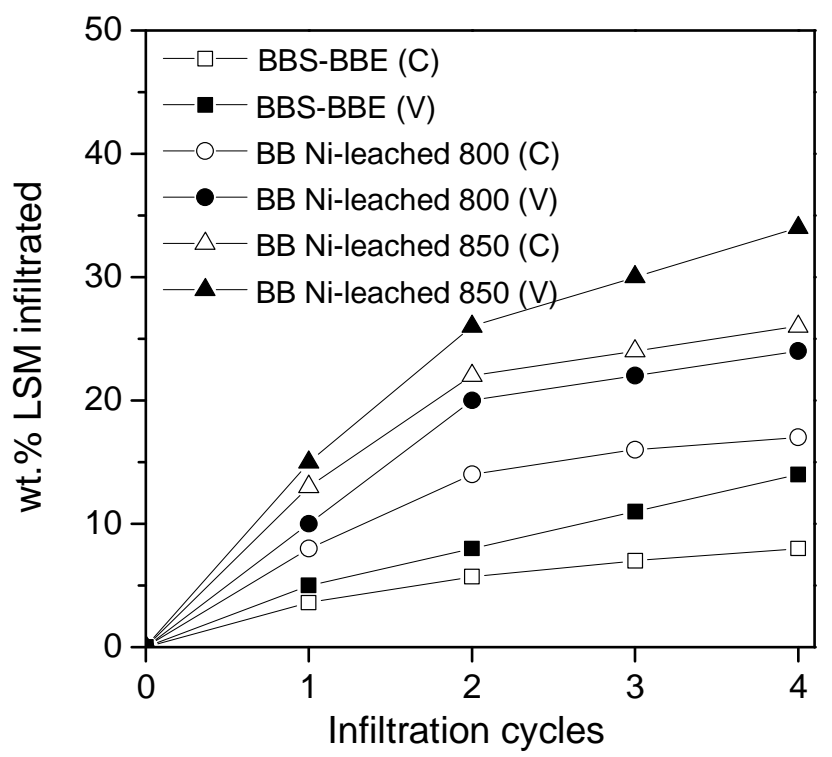

Figure 5. Effect of infiltration method, conventional (C) vs. vacuum (V) on the wt.\% LSM infiltrated into the backbones.

\section{Electrochemical characterization}

Results on the electrochemical characterization can be found in Figure 7. It is seen that there is a markedly difference in the overall resistance of the symmetrical and quasisymmetrical cells, depending on the backbone used. The lowest polarization resistance is found for the symmetrical cell, showing that all the infiltrate backbones have a higher polarization resistance than the screen printed cathodes. The highest $\mathrm{Rp}$ is found for the cells with the porous YSZ support made by nickel etching, However, the difference between the Ni etched cell and the cell with a LSM/YSZ support is not that large. The detailed EIS study reveals three arcs, see Figure 8. The arcs can be attributed to four processes as described in the literature [12]. The high frequency arc is most like due to transport of oxide ions between LSM and YSZ and through the YSZ of the composite. The second arc can be attributed to competitive elementary processes in the overall oxygen reaction mechanism. The low frequency arc is probably due to gas diffusion in a stagnant gas layer above the electrode.

\section{Conclusions}

In this work, we demonstrate that it is feasible to prepare cathodes by LSM infiltration into porous structures, obtained either using pore formers or from a Ni-leaching process. The LSM nanoparticles impregnated along the YSZ network are well connected and as consequence a good percolation is ensured, achieving Rs similar to standard cathodes when LSM-YSZ is screen printed. When the porous backbone is consist of LSM-YSZ composite Rs 4 times lower are measured, may due to the presence of not only LSM nanoparticles but also LSM grains which improve the electronic conductivity through the cathode. The method enables the possibility of producing cathode supported cells, based on pre-sintered porous backbones with other catalysts where any phase solid reaction and/or thermal expansion coefficient mismatch during high sintering temperatures is avoid. 

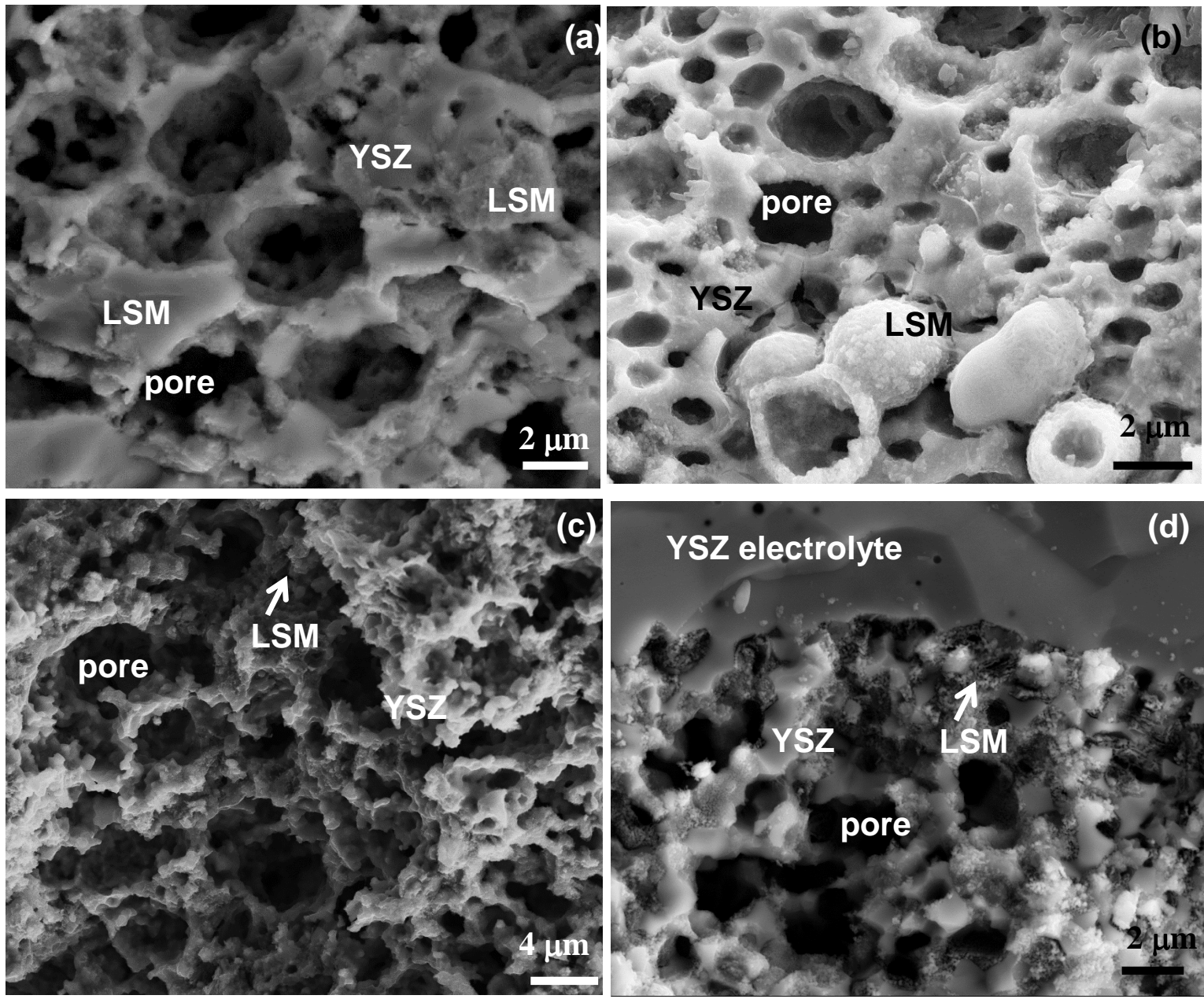

Figure 6. Cross-sectional SEM images of LSM infiltrated (a) BBS backbone (LSM-YSZ) (b) BBE backbone (YSZ) (c) BB backbone (YSZ from Ni-leached sample and (d) detailed BB micrograph.
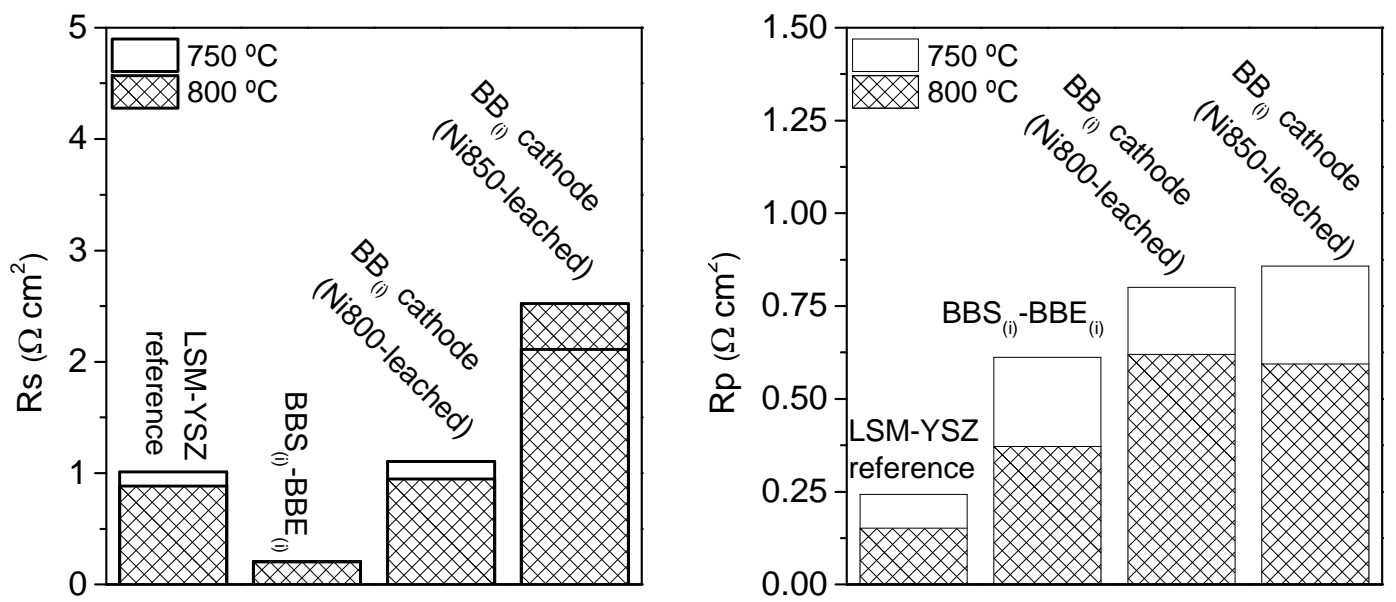

Figure 7. Ohmic resistance, Rs, and polarization resistance, Rp, of the LSM infiltrated cathodes (i) compared to LSM-YSZ screen printed (reference). BB cathodes are made from Ni-YSZ samples reduced at 800 or $850^{\circ} \mathrm{C}$ prior to $\mathrm{Ni}$ etching process. 


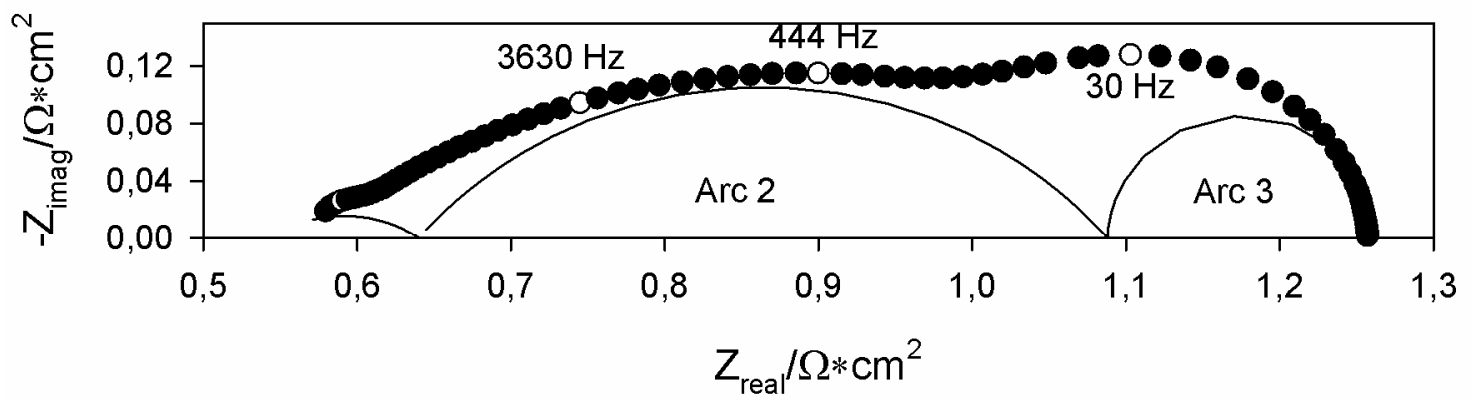

Figure 8. An example of an EIS spectrum recorded at $700{ }^{\circ} \mathrm{C}$ in $20 \% \mathrm{O}_{2}$ in Ar. The spectrum reveals three arcs.

\section{Acknowledgments}

This work was funded by the European Commission Research Fund for Coal and Steel, as the Efficient Conversion of Coal to Electricity-Direct Coal Fuel Cells project.We recognize and thank Dr. D. Ippolito at the DTU Department of Energy Conversion and Storage for helpful discussions.

\section{References}

1. B. C. H. Steele, Solid State Ionics, 75, 157 (1995).

2. T. Ishihara, H. Matsuda, Y. Takita, J. Am. Chem. Soc., 116, 3801 (1994).

3. Z. Shao, S. M. Haile, Nature, 431, 170 (2004).

4. S. J. Skinner, J. A. Kilner, Solid State Ionics, 135, 709 (2000).

5. Euro. Pat. P.V. 1513796 (1968).

6. A. O. Isenberg, Solid State Ionics, 3(4), 431 (1981).

7. A. Hauch, C. Birkl, K. Brodersen, P. S. Jørgensen, A1007, p. 1, Proceeding in $10^{\text {th }}$ European SOFC Forum (2012).

8. K. Andersen, F. Bræstrup, K. Kammer Hansen, Ceramics International, 39, 2159 (2013).

9. P. H. Larsen, C. Bagger, S. Linderoth, M. Mogensen, S. Primdahl, M. J. J'rgensen, P. V. Hendriksen, B. Kindl, N. Bonanos, F. W. Poulsen, and K. A. Maegaard, in Solid Oxide Fuel Cells VII, H. Yokokawa and S. C. Singhal, Editors, PV 2001-16, p. 28, The Electrochemical Society Proceeding Series, Pennington, NJ (2001).

10. M. V. Williams, E. Begg, L. bonville, H.R. Kunz, J.M.Fenton, J. Electrochem. Soc., 151, A1173 (2004).

11. S. F. Corbin and P. S. Apté, J. Am. Ceram. Soc., 82(7), 1693 (1999).

12. M.J. Jørgensen and M. Mogensen, J. Electrochem. Soc., 148(5), A433 (2001). 